\title{
Beyond Capitalism and Liberal Democracy: On the Relevance of G.D.H. Cole's Sociological Critique and Alternative
}

\author{
Charles Masquelier and Matt Dawson \\ Universities of Surrey and Glasgow
}

\begin{abstract}
This paper argues for a return to the social thought of the often ignored early $20^{\text {th }}$ Century English thinker G.D.H. Cole. Cole combined a sociological critique of capitalism and liberal democracy with a well developed alternative in his work on Guild Socialism bearing particular relevance to advanced capitalist societies. Both of these, with their focus on the limitations on 'free and unfettered service' in associations and the inability of capitalism to yield emancipation in either production or consumption, are relevant to social theorists looking to understand, critique and contribute to the subversion of neoliberalism. Therefore, we suggest that Cole's associational sociology, and the invitation it provides to think of formations beyond capitalism and liberal democracy, is a timely and valuable resource which should be returned to.
\end{abstract}

Keywords associational sociology; G.D.H. Cole; critique; liberal democracy; neoliberal capitalism

In 2010, Routledge published new editions of some of G.D.H. Cole’s works. While a highly welcomed decision, little room was made for the distinctively sociological works of Cole, such as Social Theory (1920) and Essays in Social Theory (1950). This did not come as a surprise, for Cole was, and continues to be known, for his political ideas and activism. A close inspection of his works, including the most ostensibly political ones such as Guild 
Socialism Restated (1980), nevertheless reveals an acute interest in sociological theorising. His rejection of what he viewed as an 'isolation of specialized studies from the general study of Society as a whole' (Cole, 1950: 29) in early $20^{\text {th }}$ century British sociology ${ }^{1}$ meant that he consistently sought to articulate sociological concerns with those of a political nature. Thus, although a sociological perspective is clearly discernible in his work, it assumes a distinctive form, combining both a critical and normative outlook.

Imbued with the task of stimulating large-scale social change and shaping its direction, Cole's works were underpinned by the typically modernist concern for the development of emancipatory practices, particularly discernible during his Guild Socialist phase. ${ }^{2}$ In this article we demonstrate what this has to offer social theory today by exposing both the distinctiveness of his perspective and its relevance to contemporary conditions. There have been attempts to revive Cole for contemporary discussion, most prominently in the work of Hirst on associative democracy (Hirst 1994). Hirst returned to Cole’s ideas - which we will discuss below - of free association and functional representation (despite the criticisms he offers of Cole's conception of this, Hirst 1994:45) as central to a new social and political

\footnotetext{
${ }^{1}$ See Dawson and Masquelier (2015) for more detail on Cole’s relation to sociology in Britain

${ }^{2}$ Such a phase, characterised by a 'politics of democratic persuasion and individual freedom' (Stears, 2006: 274) is often distinguished from later concerns regarding socialist strategy and tactics and the acceptance of a positive role for the state and planning in international affairs, in response to the political and economic crises of the 1920s and 1930s (Holthaus, 2014), for Wright (1979) Cole moves from guild socialism to 'liberal socialism' in an attempt to defend the British order against fascism. Although he is said to have eventually returned to his initial libertarian concerns (Stears, 2006), Cole never really abandoned the view that 'Socialists [...] do not regard the increase in State control over economic affairs [...] as marking any advance towards a Socialist system' (Cole, 1938: 204) and in his final book argued 'I feel sure that a Socialist society...must rest on the widest possible diffusion of power and responsibility, so as to enlist the active participation for as many as possible of its citizens in the tasks of democratic self-government' (Cole 1960: 337). Therefore, while throughout the rest of the article we will refer to Cole's guild socialist 'phase', by this we mean the period (mainly from 1917-1925) in which Cole was an active member of the guild socialist movement and used its terms, without also saying that this was a normatively distinct phase of Cole's oeuvre.
} 
order. While Hirst's work, along with that of other writers we will discuss below, has been admirable in its attempt to demonstrate Cole's relevance to the current day, these share two factors which we aim to move away from in this article. Firstly, in such arguments, Cole is presented primarily as a political theorist, with his associational view seen as political 'pluralism'. Secondly, in doing so, some commentators such as Stears (2006) have seen Cole's pluralism as innately socialist, while others have downplayed the connection of Cole's normative pluralism to his critique of capitalism (See for example Hirst 1994:19). Contrary to such accounts, we shall present Cole as a sociologist who spoke about the value of a normatively-driven sociological approach and decried those who had adopted a Weberian value-free perspective (Cole 1957c).

We shall begin by drawing the broad contours of what we term his 'associational sociology'. This will include highlighting the importance of a sociological reading of Rousseau on Cole's thought and how he distances himself from Durkheim. It will then be shown how his sociological stance informed his own critique of capitalism and liberal democracy. Here we note similarities and differences between Cole's critique and that of Marxism, as well as his value as potential critic of neoliberalism. This will be followed by a discussion of his sociological alternative, marked by a focus on the potential for associative action and its political representation. We will also discuss some of the key tendencies towards social change Cole identified, and their relevance to present-day conditions.

\section{Drawing the Contours of Cole's Associational Sociology}

Cole was a prominent figure in the short-lived Guild Socialist movement of the early twentieth century. The movement located associative life at the centre of its socialist vision, treating it as the principal precondition for emancipatory practices. For Cole, associative 
action is not so much a utopian vision to force onto social life as an essential component of any pre-existing social organisation. This is explained by the fact that 'almost every individual in [society] has [...] close contacts with many diverse forms of social institution and association' (Cole, 1920: 4). As trade unionists, members of a sports team or political party, at the workplace or in their leisure time, individuals often share a 'common purpose or purposes' and 'rules of common action' which are essential components of associative action (Cole, 1920: 37). This led Cole to treat the 'action of men in association' as 'the subject matter of social theory' (Cole, 1920: 17). Associative action itself, then, presupposes all forms of social organisation and, correspondingly, acts as an essential medium for the development of societal norms and value structures.

For Cole, then, associative action is a social fact and sociology's most fundamental unit of analysis. But how does he explain individuals’ willingness to enter into association with others and adopt cooperative forms of action? Two dimensions can be found in Cole's explanation. The first one focuses on the rational component of associative action, where '[t]he consciousness of a want requiring co-operative action for its satisfaction is the basis of association' (Cole, 1920: 34). The 'want' in question can assume a multitude of forms, ranging from the production of a material requirement, fulfilling our consumer needs, or the pursuit of non-economic interests. These are satisfied through the spheres of production, consumption and civic activity (Cole 1920) respectively. The second element is a deeper, affective, dimension where individuals engaging in cooperative action are 'led to do so by a strong impulsion of the sentiment of social solidarity' (Cole, 1950: 128). The existence of a multitude of social organisations and the possibility for social order are therefore explained by the fact that individuals are cooperative beings by nature. 
Despite such a prominent emphasis on associative/cooperative action, his sociological perspective is first and foremost one concerned with the problem of human emancipation. Along with Laski and Tawney, Cole developed a 'new brand of individualism' (Stears, 2006: 102), that sought to remedy the apparent problems associated with the overly communal nature of freedom found in Figgisian pluralist thought (Stears, 2006). His works emphasised individuals' continuous desire to maximise their 'personal liberty' (Cole, 1920: 184). Understood as a form of pleasurable self-expression achieved by the release of the 'creative, scientific and artistic impulses' (Cole 1980, 115-6), his approach to emancipation echoes Marx's call for the 'open revelation of human faculties' in his Economic and Philosophical Manuscripts (2000: 102). ${ }^{3}$ It also exhibits features of the reconciliation of sensuous and rational faculties advocated by first generation Frankfurt School theorists (Masquelier, 2014).

He was nevertheless critical of the scientific component of the 'Marxian method' (Cole, 1948: 14) for its tendency to dissolve the 'constructive influence of the minds of men' (Cole, 1948: 34) as well as for the corresponding 'error to attribute to "classes" [...] any reality distinct from that of the individuals which compose them' (Cole, 1948: 11). Insisting that 'men make their history,' he hoped to formulate a sociological perspective in which individuals' own capacity to both control and alter their conditions of existence is fully recognised. To do so, he thought, one had to re-assess the respective place held by the general (class structures/consciousness) and the particular (individual agents') conceptions of the good life. The reality of the former had to be re-aligned with that of the latter.

\footnotetext{
${ }^{3}$ Cole's work, however, shows no evidence that he had read this particular text, which may have been translated in English too late for Cole to get a chance to engage with it.
} 
In order to better grasp how Cole attempted to solve the riddle of this relationship, exemplified by the antagonism between liberals and communitarians (Eisenberg, 1995), ${ }^{4}$ one has to turn to the inspiration he drew from Rousseau, particularly his concept of general will. In doing so, we can see that Cole turned to Rousseau for sociological inspiration rather than treating him as a strictly political figure. Indeed, while he admired Rousseau for treating the will to cooperate as derivative of an innate impulse towards sociality, Cole also praised his views on the effects of associative action on the relationship between individual and collective conceptions of the good life. He interpreted such a relationship as follows:

whenever [individuals] form or connect themselves with any form of association for any active purpose, [they] develop in relation to the association an attitude which looks to the general benefit of the association rather than their own individual benefit. This is not to say that they cease to think of their own individual advantage - only that there is, in their associative actions, an element, which may be stronger or weaker, of seeking the advantage of the whole association, or of all its members, as distinct from the element which seeks only personal advantage. (Cole, 1950: 114)

Here associative action resurfaces not merely as the product of a will but also as the source of social organisation whose object 'is not merely material efficiency, but also essentially the fullest self-expression of all the members' (Cole, 1920: 208). The purpose of the association itself is therefore construed by Rousseau (and Cole) as an extension of individuals' own interests/will. Consequently, the 'personal freedom' (Cole, 1917: 5) associations succeed in facilitating becomes both constitutive of and constituted by the common good embodied in the general will of each association. The freedom arrived at here, therefore, does not consist of an unlimited, unhindered or absolute right to act as one pleases, such as Rousseau's 'natural freedom' (Simpson, 2006). Instead, it takes the shape of a form of moral autonomy

\footnotetext{
${ }^{4}$ Communitarianism should here be understood as a political-philosophical stance giving a central place to the values of a group, often at the expense of individual conceptions of the good life.
} 
entailing 'obedience to the law which we prescribe to ourselves' (Rousseau, 1993: 196). Cole nevertheless insists that despite its 'rational precepts,' this moral freedom 'finds an echo in the heart of the 'natural man,"' with '"human feeling” as its motivating force' (Cole, 1993: liii-liv). Therefore, moral freedom and its realisation in the associative will is a building block of sociality.

Alongside such a concern for the maximisation of personal freedom in associations, one finds what Stears characterised as Cole's 'obsession with complex and competing social allegiances' (2006: 99). Their very existence, he thought, meant that in order to remain truly free, individuals could not owe allegiance to a single authority, but would instead develop different categories of 'loyalties' and 'obligations' (Cole 1926). These are determined by the type of association - producer, consumer or civic - to which individuals belong. Since they develop through associative action, however, these loyalties and obligations are not obstacles to autonomy. Instead, they are both a desirable and necessary component of associative life giving 'men [sic and throughout this article] the fullest possible scope for creative activity' (Cole, 1950: 97). It is their capacity to accommodate the principle of 'self-government' (Cole, 1917) and, as Warren recently put it, yield a 'power to make collective decisions' through 'equal participation in collective judgment' (2001: 60) that associations can, in principle, be expected to pave for the way for agency (see Lamb, 2005). It is through our associational activity that, both historically and in day-to-day actions, agency is achieved, alongside the personal/creative development of the individual. ${ }^{5}$

\footnotetext{
${ }^{5}$ Although Eisenberg highlighted Cole's incapacity to achieve such a goal by failing to 'understand the need for diversity' and personal development (1995: 74), it seems that Cole was more conscious of such issues than she allows him to be. For example, in Essays in Social Theory, Cole emphasises the need to recognise the 'continuous adaptation to changing needs and growing knowledge' (Cole, 1950: 74). Such an oversight could be explained by the fact that Eisenberg drew her claims from only one of Cole's work, namely Social Theory (1920)
} 
Cole identified one last essential feature of the form of associative life organised around the principle of 'self-government.' Having observed the development of a 'spirit of free communal service' (Cole, 1980: 44) in the medieval guilds, Cole envisaged a similar development in associations. To be able to yield such a 'spirit,' he argued, the individual 'must feel that he is enjoying real self-government and freedom at his work; or he will not work well and under the impulse of the communal spirit' (Cole, 1980: 49). This can be achieved where associations substitute the 'motives of greed and fear' (Cole 1980: 45) with the 'motive of free service' and 'breed men capable of being good citizens both in industry and in every aspect of social life' (Cole, 1980: 61). Consequently, associations must free themselves from any distortion capable of undermining the fine balance between individual conceptions of the good life and the common good. ${ }^{6}$

To summarise, associative action is central to Cole's sociology, as it constitutes an innate impulse towards sociality, it is thought to be beneficial, if not essential, for human emancipation and the development of a solidaristic outlook. In doing so, Cole shares similarities with Durkheim not only in associative action's role in the development of solidarism, but also in the means (guilds/corporations) to achieve this. Indeed, Cole spoke positively of Durkheim's work as an indication of the kind of social science combining analysis of the political and economic, which he favoured (Cole 1934: 3). A full exposition of these links is beyond this paper (see Dawson 2013: 62-83). However, there are some

\footnotetext{
${ }^{6}$ Like Habermas, Cole sought to protect interpersonal relations against the distorting effects of money and power. However, Rousseau's influence on Cole's wish to turn 'sentiment' into 'a force in the shaping of human affairs' (Cole 1950, 128), led him propose a different relationship between 'reason ordering and will acting' from the one found in Habermas's work (Habermas 1989, 82). Indeed, while the latter effectively dissolved 'will acting' in 'reason ordering' within his theory of communicative action (See Masquelier 2014), Cole attributed a central role to actions driven by the 'will' of individuals.
} 
differences. Most notably, Cole emphasised what he saw as the 'conservative' nature of Durkheim's theory and its lack of materialism. For Cole, it was capitalism which gave society its value structures and Durkheim marginalises this in seeing religion as the base of society (Cole 1952:127). This is why Cole formulated his associational sociology alongside a stringent critique of the capitalist economic and socio-political institutions based on the very sociological premises detailed above. It is to this critique and a demonstration of its relevance to contemporary conditions that we shall now turn.

\section{From Associational Sociology to a Critique of Capitalism and Liberal Democracy}

Cole's associational sociology informed the core postulates of his critique of capitalism and liberal democracy. As an economic system favouring profit over need; competition over cooperation; efficiency and productivity over 'pleasure in work well done' (Cole, 1980: 61); and 'greed [...] and fear' over 'free and communal service' (Cole, 1980: 44-5), it failed to give scope to ‘man’s natural qualities’ (Cole, 1917: 256). Consequently,

[t]he crowning indictment of capitalism is that it destroys freedom and individuality in the worker, that it reduces man to a machine, and that it treats human beings as means to production instead of subordinating production to the well-being of the producer. (Cole, 1917: 24)

Not only was 'the primitive social impulse [...] overlaid by bad institutions' (Cole, 1950: 129), the latter also destroyed personal freedom while causing the 'failure of the association so affected to fulfil its proper function in Society’ (Cole, 1950: 145). Despite not having lived long enough to be able to witness capitalism's latest evolutions, a close reading of his work reveals a contemporary relevance to societies under the rule of neoliberal economic and political forces, some of which will be discussed in this section. 
A first key dimension of his critique relates to the sphere of production. Drawing his inspiration from William Morris, Cole wrote extensively on the problems emanating from an ‘impulse towards self-expression thwarted by commercialism’ (Cole, 1980: 119). Like Morris, and unlike Durkheim, Cole was a fervent critic of the division of labour, with a particular concern for its tendency to 'divorce the executant from the designer or planner' and the resulting loss of the 'dignity of common labour' (Cole, 1957a: 9). Like the early Marx, he treated production as a central outlet for self-expression and cooperative action. ${ }^{7}$ Correspondingly, he equated the increased specialisation of tasks engendered by the subordination of workers to a productivist regime of capital accumulation with a loss of control fatal to production's essential role in the release of 'creative, scientific and artistic impulses.' Cole, here, would have also been at home with critics of Fordist scientific management on production, such as Braverman (1974).

Since the 1970s, however, innovative methods of production have emerged that are often said to have marked the emergence of a 'post-Fordist' regime of accumulation aimed at overcoming the rigidities of its predecessor (Harvey, 1989; Kumar, 1995). Despite postFordism's relative success in achieving a degree of 'elimination of job demarcation' (Harvey, 1989: 177), managerial horizontalism (Kasmir, 1996) and a generally 'enhanced work satisfaction for the bulk of workers' (Kumar, 1995: 47), contemporary commentators have highlighted its limited capacity to yield authentic and lasting self-expression. This state of affairs, it is argued, derives from production processes subjected to highly flexible, globalised and competitive labour markets and privatised resources geared towards the 'accommodation of ceaseless change' (Piore and Sabel, 1984: 17). Often, then, the central

\footnotetext{
${ }^{7}$ As Stears (2006) and Holthaus (2014) noted, Cole did nevertheless express doubts regarding the treatment of production as a potential sphere of pleasurable self-expression following the demise of the Guild Socialist movement and the economic crisis.
} 
resultant of the rule of these neoliberal economic forces is described as an intolerable economic insecurity causing the erosion of loyalties and obligations; or, as Sennett (1998) put it, 'the corrosion of character'.

The objective character of such insecurity has been disputed by Doogan whose empirical analysis revealed that "job stability has not declined and that long-term employment has increased in many sectors of the advanced economies' (Doogan, 2009: 4). It follows that in order to find an explanation for the sense of insecurity dominating neoliberal societies, one has to move away from the widespread view that the material impact of neoliberalism encourages insecurity, towards a diagnosis more inclined to accept the notion of distortion of the associative will proposed by Cole. Doogan offers a convincing Bourdieusian reconceptualisation of insecurity by treating it as an ideological tool employed for 'both political ends and political advantage' (Doogan, 2009: 10). But, Cole’s work makes its own contribution to the diagnosis by concentrating on the effects of 'bad institutions' - most notably capitalist markets and corporations - on individuals and, more specifically, their capacity to achieve associative self-expression. For, with Cole's critique of capitalist institutions, the neoliberal 'rhetoric' of self-reliance and self-responsibility deconstructed (and condemned) by Bourdieu and Wacquant (2001: 4), comes to be treated as a barrier to both the rational and sentimental motive of associative action. Under its spell, individuals cope with the sense of insecurity through an intensified competitive pursuit of self-interest or ‘rugged individualism’ preventing any inclination towards the communal spirit experienced as a desirable or natural end. The resulting disconnection between individual interests and the common good means any form of freedom granted by neoliberal market forces becomes meaningless. This is explained by the fact that it divorces the longing for secure selfexpression or control, from the form of associative action that could give them the 
‘confidence without which freedom can hardly be exercised’ (Bauman, 2005, 36). Therefore, adapting elements of Cole's critique of capitalism to a critique of marketization processes unfolding under the rule of neoliberalism, makes it possible to gain a fresh insight into the 'normative fragmentation of [neoliberal] societies' (Crouch, 2011: 180).

Moreover, Cole's critique did not, as did most Marxian critiques of his time, limit itself to problems associated with production. Conscious of the fact that the individual worker did 'not find his job interesting or pleasurable and seeks his pleasure outside it, in his hours of leisure' (Cole, 1957b: 16), he expressed an early interest in exploring matters regarding consumption. Cole quickly came to realise that consumption was subjected to very similar repressive forces to those found in production. Like producers, he argued, consumers lacked the capacity to exert sufficient control over the decisions taken within their own sphere of activity. By 'dictat[ing] the consumer what he shall consume' and 'exploit[ing] the community as the individual profiteer exploits it to-day’ (Cole, 1917: 108), commercial agencies deny individuals the 'freedom for the creative impulse' as well as for 'the impulse of free and unfettered service' (Cole, 1917: 302). While neoliberal regimes have made markets more responsive to consumer demands, thereby recognising that 'wants are of the most diverse character' (Cole, 1920: 33), this development has also been accompanied by a further atomisation of society. Any potential for collective 'control of consumption' (Cole 1917: 281) is lessened under such a regime. Once again, then, Cole’s own condemnation of the distortion of a potential sphere of self-expression and associative action by divisive economic forces appears to bear striking relevance to present conditions. In fact, like Bauman, Cole viewed the solitary search for pleasure in consumption as an insufficient condition for an effective and sustained gratification - or what Bauman (2000) would call 'de facto individualisation' - dependent on forms of collective control heavily distorted by 
untrammelled market forces. ${ }^{8}$ Therefore, while Cole shared the emphasis on consumption as a realm of identity found in contemporary sociology, he combined this with a materialist critique of its atomised form.

Cole also took the care of explaining what he thought were the causal origins of such distortive tendencies:

In our own Society at least, and in the larger industrialised communities generally, economic divisions are at the present time the principal obstacles to the fulfilment of social functions. (Cole, 1920: 151)

Therefore, in common with Marxian ideas of the conflict between labour and capital, Cole wished to emphasise the highly distorting effects of such a conflict on the experience of associative action. Under a clearly identifiable relationship between ownership and control, such as the one found under the early capitalist stage, the conflict of interest between the capitalist owner and wage labourer visibly lies at the root of the some of the major obstacles to cooperation and self-expression. Once wage labourers come to include 'technical specialists, managers, financial experts, buyers and agents whose status and remuneration were a long way above those of the manual workers and of workshop foremen and supervisors' (Cole, 1938: 102), one witnesses a 'blurring of class-divisions' (Cole, 1938: 128) posing new challenges for collective action. While, as Cole observed, such a state of affairs, partly driven by the spread of 'financial capitalism' (Cole, 1938), did not prevent the 'growing concentration of control of capital' (Cole, 1938: 126) it did divide the working-class movement (Cole, 1948: 155). The historical significance of a new and 'greatly differentiated' proletariat comprising many 'grades of labour and levels of incomes and education' (Cole,

\footnotetext{
${ }^{8}$ For a more detailed discussion of the affinity between Cole and Bauman, see Dawson (2013).
} 
1948: 171), such as the one found in the neoliberal age, was therefore anticipated by Cole in the immediate post-war era.

Thus far we have highlighted the following critiques from Cole: the lack of self-expression in work; the distorting of 'free and unfettered service' in associations; lack of control in consumption, the origins of economic distortion and the fragmented nature of class inequality. However, additional effects of these inequalities can also be identified beyond the economic sphere, making Cole's critique also one of the political. Cole viewed the modern state as 'an organ of class domination' both 'perverted by the power of the capitalists' and 'based on coercion’ (Cole, 1980: 122). Here he argued that the liberal democratic conception of the state as a 'self-subsistent and individual realit[y] similar to, or greater than, the persons who are members of [it]' (1920: 22), not only acts as a barrier to the political representation of the plurality of interests making up social life, but also embodies a 'conception of human society in terms of Force and Law' (Cole, 1920: 6). Consequently, liberal democracy is said to rely on a conception of the common good which it has to manufacture in the face of 'contending sections' (Cole, 1920: 150) found in a highly hostile capitalist economy. As the effective product of competing interests, then, the capitalist state ultimately fails to recognise ‘the motives which hold men together in association' (Cole, 1920: 6); it fails to recognise the associative wills.

Cole was therefore conscious of, and indeed highly concerned by, the tendency of socioeconomic inequalities to undermine the democratic character of political decision-making. His critique of liberal democratic institutions is therefore first and foremost a critique of capitalism. The 'predominance of economic factors' (Cole, 1980: 180) found in societies whose (economic and political) institutions are oriented towards capital accumulation, 
effectively distorts decision-making processes. The result of this is the reproduction, at the political level, of the conflictual relations found in the economy, coming to undermine the forms of collective control necessary for truly democratic action. Cole, then, 'treated the influence of economic factors upon non-economic forms of association as a form of perversion' (Cole, 1920: 145). However, since Cole wrote most of his works during the liberal stage of capitalist development comprising a state seeking to minimise its role in economic affairs, he did not live long enough to witness the emergence of the neoliberal state. This 'distinctive form of [the neoliberal] state’ (Jessop, 2002: 95) is, contrary to its liberal counterpart, clearly 'proactive in promoting the competitiveness' of its economic space 'in the face of intensified international [...] competition' (Jessop, 2002: 124). Today one finds political forces playing a central role in eliminating barriers to the free accumulation of capital, e.g. labour rights, and promoting 'economic and extra-economic conditions' (Jessop, 2002: 95) leading to 'huge transfer of public funds to private power' (Chomsky, 1999: 67-8). If one adapts Cole's logic of reasoning to the present situation, one no longer merely finds the state, as social organisation, falling victim to economic 'perversion,' but rather sees this institution as one of its key culprits, reflecting contemporary arguments concerning the statist nature of the supposedly anti-statist neoliberal project (Harvey 2005). In fact, in Cole’s work, one finds a range of sociological considerations with which to better appreciate the full scope of the perverse effects of neoliberal forces on society, by complementing the Marxian critique of the state's role in promoting the interests of capital with a critique of its role in distorting associative life.

Furthermore, Cole consistently deplored the fact that the political system had developed into a 'single omnicompetent representative assembly' (Cole, 1920: 108) attempting to manage a 'vast society which changed its basic structure so fast that the magnitude and growing 
complication of its problems outran hopelessly their capacity to learn the difficult art of collective control' (Cole, 1950: 91). The key issue at hand here is the incapacity of the state to promote ‘active [...] citizenship’ (Cole, 1920: 113). On the one hand, Cole takes issue with the form of representation entailed by liberal democratic decision-making processes, which continue to predominate in contemporary Western political systems. Their inadequacies, he argues, is explained by the fact that 'as soon as the voters have exercised their votes, their existence as a group lapses until the time when a new election is required' (Cole, 1920: 110). Since 'no man's will can be treated as a substitute for, or representative of, the wills of others' (Cole, 1920: 103), liberal democracy is based on a 'false theory of representation' (Cole, 1920: 103). In short, it excludes the forms of associative action necessary for truly active political participation.

Although Cole lived long enough to witness the gradual expansion of the state's administrative apparatus following the political and economic crises of the 1920s and 1930s, he had already expressed concerns regarding the effects of bureaucratisation on personal freedom prior to this period. For Cole, the key problem with such a 'machinery' was not its size but its very nature (Cole, 1918: 36). In addition to the problems of representation mentioned above, bureaucracy manages all affairs from the 'point of view of "efficiency”" and at the expense of 'full and complete' freedom (Cole, 1918: 25). By subsuming individuals' variegated interests under the universal yardstick of economic efficiency, it is thought to bear restrictive effects on individuals' actions. Bureaucracy, then, is yet another political institution restricting the freedom of individuals and an additional instance of the perversion of the political sphere by economic interests under capitalism. Initially, then, it seems that Cole would have welcomed the neoliberal critique of the bureaucratic state. However, upon closer examination, what Cole's critique of political institutions under 
capitalism - including his critique of bureaucracy - seems to offer is a basis upon which to grasp such measures as yet another, and indeed more total, instance of economic perversion. Adopting Cole’s own reasoning, then, individuals could be said to end up more directly and completely exposed to volatile economic forces ultimately responsible for increased economic insecurity, sharper socio-economic inequalities and de-solidarisation under the neoliberal regime. Consequently, had Cole lived long enough, he would have surely condemned the role played by an increased exposure to market forces and their evidently pernicious effects on the 'motives which hold men together in association.'

In his critique of liberal capitalism, then, Cole grappled with the obstacles to human emancipation by condemning the perverse and distorting effects of 'bad institutions' on selfexpression and associative action. Under the guise of neoliberal capitalism, one finds a historically specific configuration of economic and political forces further undermining the capacity for collective control and authentic self-expression. Flexible labour and consumer markets, sharp socio-economic inequalities and the 'competitive Schumpeterian state' (Jessop, 2002) all affect social relations in a particular way. More specifically, they lead to a divorce of the pursuit of self-expression from the 'primitive social impulse,' further subject individuals to the divisive rule of market forces and impose additional barriers to political representation of social plurality. Here we see his critique was not simply a realisation of a pluralist political position, as suggested by others (Hirst 1994), but rather one founded on a Rousseau-ian sociological base.

Despite such obstacles to human emancipation, however, the present situation offers new opportunities for radical social change. The next section shall therefore aim to expose them, while highlighting the relevance of his libertarian socialist alternative to neoliberalism. 


\section{Bringing Associative Action to Life}

In the first chapter of Guild Socialism Restated, Cole described the task of the guild socialist, i.e. his own task, as follows:

He [the guild socialist] claims, not to be imagining a Utopia in the clouds, but to be giving form and direction to certain quite definite tendencies which are now at work in Society, and to be anticipating the most natural developments of already existing institutions and social forces. (Cole, 1980: 11)

Some of these 'definite tendencies' were highlighted above and demonstrate the grounded, sociological, nature of his critique and alternative. There, it was shown that Cole treats associative action as a necessary - and therefore pre-existing - condition for all forms of social organisation including present ones, and places it at the core of his sociological approach. Under the spell of capitalist economic interests, associative action does not vanish, it merely becomes subsumed under the ethos of competitive individualism, economic efficiency and a coercive political machine. Cole’s task consequently consists in creating conditions under which the associative spirit or will can thrive and become the central force mediating social relations, i.e. to substitute 'bad' institutions with 'good' ones.

Cole's remedy to the ills of capitalism assumes the form of a libertarian socialist alternative which aims to re-organise society in such a way as to 'afford the greatest possible opportunity for individual and collective self-expression to all its members' (Cole, 1980: 13). Voluntary, open, inclusive and democratic associations are here the chosen form of social organisation, for in them individuals are thought to be in the best position to 'agree[...] together upon certain methods of procedure, and lay[...] down, in however rudimentary a form, rules for common action' (Cole, 1920: 37). The democratic and generally cooperative character of practices flourishing within such associations are treated by Cole as ideal conditions for the 
development of a 'communal spirit' (Cole, 1980: 46) and the elimination of the various 'hindrances' to self-expression such as inequality, bureaucratic managerialism and the division of labour. Thus, in virtue of their capacity to give full scope to horizontal decisionmaking processes, democratic associations play a central part in Cole's attempt to 'offer the means to resolve the familiar tensions between political power and individual development' (Eisenberg, 1995: 5). ${ }^{9}$ This, in fact, partly explains its appeal to political theorists as a third way when shorn of its anti-capitalist elements.

Various additional conditions for emancipation were laid down by Cole. Firstly, he believed that the realisation of such conditions was predicated upon 'self-government on the smallest natural units of control' (Cole, 1980: 101). The close interpersonal proximity these 'small units' tend to confer would facilitate the development of values of 'cheerfulness, comradeliness, co-operativeness, consideration, kindness' (Cole, 1950: 7). By 'natural’ Cole meant '[m]en's easiest ways of grouping' and, as such, refer to units such as 'the places they live in and the places they work in' (Cole, 1950: 107). Both the size and locality of associations are therefore treated as important factors by Cole, for these conditions are instrumental in shaping the spirit of fellowship and facilitating the representation of the plurality of interests making up social life. In a complex and differentiated neoliberal world, whereby 'differences pile up one upon the other' (Bauman, 1997: 13), Cole’s associations would not only provide means for the institutional recognition of plurality, but would also serve to alleviate the 'overwhelming sensation of insecurity' (Bauman, 1997: 204) accompanying it. For Cole, this re-organisation of social life could only be achieved through a re-organisation of economic life.

\footnotetext{
${ }^{9}$ Although Eisenberg makes this claim with regards to the potential of political pluralism in general - not Cole's own - it was shown above that Cole does succeed in combining both elements.
} 
To the 'industrial autocracy of capitalism' (Cole, 1980: 51), Cole opposed 'a free [economic] system [that] will bring to the front man's natural qualities - his sense of fellowship, his desire to express himself' (Cole, 1917: 256). Such a 'free system,' would alter the experience of producers in such a way as to 'make the enterprise he works in a success, not in terms of profit, but in terms of rendering a good service to the consuming public, and thus contributing towards the improvement of the general standard of living' (Cole, 1957b: 36). Democratic associations of producers, the modern guilds, would not only secure the collective forms of control required for authentic self-expression, but would also substitute the 'motives of greed [...] and fear' with 'the spirit of free and communal service.' Such a spirit is, today, partly exemplified by the production of Free and Open Source Software (FOSS) programmes providing a free service while relying on a form of 'voluntaristic cooperation that does not depend on exclusive proprietary control or common relations as among the co-operators' (Benkler 2013:214), such as Mozilla Firefox or Wikipedia.

Now in a position to make collective decisions regarding the pace of the labour process and the nature of the tasks involved in making the products, members of democratically organised associations can begin to expect working conditions giving them ample scope for creative and, following Cole's reasoning, pleasurable practices. The emergence of joint-stock companies as a ‘sign of the growing ‘democratisation' of the capitalist system' (Cole, 1948: 123) could initially be said to have marked a further democratisation of the economy. Nevertheless, the limited power accorded to voters and the growing concentration of capital found in such a system (Piketty, 2014) means such bodies are associative 'only in form' (Cole, 1948: 103), thereby demonstrating the limit of capitalism's capacity to align individuals' interests with the common good. This indicates the need for structural change in 
both production and market conditions, which Cole recognised and proposed to undertake through a re-organisation of the relationship between production and consumption:

A man is usually either a miner or a railway-man, and not both; but he consumes coal, uses the railways, and only limits the variety of his consumption by his lack of opportunity. But in both the essential social differentiation is not that between individuals but that between interests or concerns, that is, between types of production and consumption. (Cole, 1980: 81)

Implicit in this passage is Cole's rejection of some elements of liberal thinking. What he partly wishes to convey here is the fact that the pursuit of freedom through self-expression does not lead to a separation or differentiation between individuals. A key failure of (neo)liberalism is to overlook the fact that the very process involved in such a pursuit entails, and is indeed most successfully accomplished through, the collaboration with other individuals sharing similar interests. In societies subjected to the logic of the capitalist market, the competitive pursuit of freedom by the producer often confronts that of the consumer as an obstacle to the latter. Here one not only finds a differentiation/separation between the producer and consumer but, more crucially, an antagonism between these parties, which assumes a particularly acute form in societies more completely exposed to the vicissitudes of market forces. Cole's proposal to rethink the relationship between them is, given the aforementioned contemporary focus on consumerism as a realm of selfactualisation, timely. He did so by pointing out a crucial feature of the process of satisfaction of needs, namely the fact that, by definition, the interests of producers and consumers are necessarily in a state of mutual dependence. Without the production of a good, the consumer is unable to use it. Without the consumption of a good, the raison d'être of a product and a producer's work vanishes. For this reason, he concluded that

the whole body of consumers and the whole body of producers are practically the same people, only ranged in the two cases in different formations. There can be no real divergence of interests between them. (Cole, 1980: 38-9) 
By rethinking the relationship between producer and consumer, Cole offers a platform upon which to re-evaluate the place held by associative action in the process of satisfaction of needs. One finds that the conditions for collective control are not confined to actions between different producers or consumers, but are equally attainable (and indeed desirable) in relations between these two spheres. It is from this stance that Cole came to design his own alternative to the capitalist market, which we shall call here the 'dialogical coordination of needs satisfaction’.

As we have seen, for Cole, actually existing emancipation rests on individuals' capacity to achieve collective control. Therefore, he construed his task as one primarily oriented towards the elimination of all hindrances to such control both within and between the spheres of production and consumption. Within the productive sphere a key indicator of such a change could be found in cooperatives, whereby the implementation of 'one member, one vote' (Cole 1948: 127) provided a basis for collective control. Their potential role in serving largescale social change has in fact recently been emphasised by several contemporary commentators (Alperovitz, 2011; Wyatt, 2011; Wolff, 2012; Shantz and Macdonald, 2013), thereby making them more likely agents of change than those Cole (1980) had in mind, namely the trade unions. Cole was nevertheless conscious of the need for cooperatives currently to submit to the demands of the capitalist market. Their potential for emancipation was necessitated on the need for public ownership and a non-capitalist market based upon the dialogical coordination of needs satisfaction. In an associative body such as the cooperative, the spirit of free and unfettered service would be secured by giving workers the means to control the labour process, and consumers the means to define their needs collectively. However, the prospects for the generalised release of this spirit rest on producers and 
consumers fully 'negotiat[ing] on equal terms' (Cole, 1917: 86). Another level of cooperation, this time between producers and consumers, is therefore required.

Here dialogical coordination comes to play a key role in virtue of making 'the fullest provision for joint consultation and action between the Guilds and the consumers' organisations at every stage, local, regional and national' (Cole, 1980: 90-1). With it, the 'invisible hand' of the capitalist market dictating the allocation of resources and limiting the effective control of producers and consumers alike vanishes, to pave the way for a consistent dialogue between representatives of associations in each of the two dimensions (supply/production and demand/consumption) of the process of satisfaction of needs. While the flexibility of post-Fordism equipped production with a stronger capacity to meet the plurality of wants and introduced 'cooperation' as a 'key managerial strategy and a dominant corporate ideology of flexible accumulation' (Kasmir, 1996: 30), it did so at the expense of economic security and consumer association as opposed to atomisation. What Cole's dialogical coordination offers is a third way which aims to achieve a combination of autonomy and security. As such, he provides means for the institutionalisation of the 'collective protection' of freedom, which Bauman himself has repeatedly urged to realise in societies subjected to the fragmentary rule of privatisation and flexibilisation (1997: 205). The freedom to choose and release of the various 'creative, scientific and artistic impulses' through production and consumption would here, Cole believed, be given the means to become a meaningful and collective endeavour. It would oppose the rather 'corrosive' (Sennett, 1998) effects of flexible labour markets and individualistic search of pleasure characterising contemporary capitalist societies, which implicitly rely on collective notions of 'good' consumption found in reference groups (Bauman, 1997) with fully emancipatory practices. In order to meet its objectives, however, the aforementioned second level of 
cooperation must develop a system of representation capable of giving the fullest scope to both consumers' and producers’ wills/interests in dialogue.

It is here that Cole makes a second distinctive contribution, but this time as the alternative to (neo)liberal democratic ('false’) representation. His critique of liberal democracy led him to rethink the relationship between the economy and politics in such a way as to overcome the perversion of the latter by the former alongside its lack of functional representation. This, he argued, can only be achieved once the distance between the representative and the represented is minimised, and channels of communication between the local, regional and national levels are fully developed. This is done in two ways. Firstly, Cole insisted on the availability of a 'right of recall' by the represented party on the representative (Cole, 1980: 134). Secondly, the 'true' representation of the general will of a local association - itself an extension of an individual's will - can only be expected under conditions whereby the purpose of the association, i.e. its function, is itself being represented. Only then could political representation give recognition to the social value of an association's function and become a real source of social empowerment, for the 'functional organisation of Society contains in itself the guarantee of the recognition of the fact that society is based upon the individuals' (Cole, 1920: 192). Representing the function of an organisation at the political level therefore entails a direct representation of an individual's will. As 'the underlying principle of social organisation' (Cole, 1920: 48), then, function ought to become the underlying principle of political representation if the latter is to be expected to give scope to personal freedom. The state as we know it would here vanish to pave the way for producer guilds and consumer councils functionally represented and coordinated by a 'commune' at the local, regional and national levels (Cole, 1980: 124). 
Given the increasingly complex and globalised nature of the contemporary world, however, one is justified in asking how Cole sought to address the problem of international relations. Such a theme was picked up by Holthaus, who convincingly demonstrated how Cole's own 'functionalism,' particularly the one found in his work following the Guild Socialist phase, could make it possible to envisage ‘democratic empowerment and transnational co-operation’ (2014: 15). Here, Cole's functionalism is said to have combined 'some economic democracy and consent about long-term economic aims' (Holthaus, 2014: 12) in an institutional vision oriented towards the international coordination of the process of satisfaction of needs. ${ }^{10}$

The global significance of Cole's thought can also be found in some contemporary global formations, most notably the alter-globalization - at least in its 'way of subjectivity' form (Pleyers 2011) - and Occupy Wall Street movements. These developed ways of organising which, in their use of groupings such as 'general assemblies' and 'working groups' in order to achieve 'horizontal' organisation around 'consensus' (Flank, 2011: 8), reflected the 'functional bodies' organised in a commune as advocated by Cole (cf. Cole, 1980: 124). The sociological value of Cole's perspective lies in the link it draws between the pluralisation of everyday life, that we engage in multiple forms of production, consumption and civic activity, and the multiple points of entry, including the functionally specific points, which he advocates for the political sphere. The diversification of movements, found in the way of subjectivity, reflects these conditions and the shift to what Boltanski terms the 'artistic critique’ which 'becomes exasperated with all which standardises, uniformises and massifies' (Boltanski 2002:6). Like Cole, then, members of contemporary social movements seek to accommodate the pluralist reality of complex and differentiated societies in highly

\footnotetext{
${ }^{10}$ Holthaus (2014) did nevertheless reveal that Cole's international thought fell short of developing a vision capable of fully excluding the state from the management of international affairs.
} 
consensual decision-making processes aimed at unleashing the free communal spirit through seemingly functional forms of representation ${ }^{11}$.

\section{Conclusion}

Keen to circumvent the aporias of mere negation and unwilling to find comfort in the belief in capitalism's self-destruction, Cole unreservedly and unashamedly construed his task as sociologist in distinctively prescriptive terms. His work not only reveals a high degree of optimism regarding individuals' capacity to become 'socially good,' but also proposes possible avenues for the attainment of such a goal. To the perversion of an innate impulse towards sociality by capitalist and liberal democratic institutions, he opposed a form of social empowerment thought to facilitate the undistorted release of such an impulse.

Like the Burawoyan (2005) public sociologist, Cole would want us to take a moral stance; to publicly condemn what one views as intolerable conditions of existence; to engage with and serve the public so as to maximise the progressive impact of sociological research. But Cole's ambition for sociology (and social sciences as a whole) also reached beyond the confines of contemporary public sociology. He did not merely seek to induce social change by stimulating indignation, but complemented the latter by an ambitious programme of action which could today serve as an invaluable source for the task of counteracting divisive neoliberal forces and reinvigorating associative life like a phoenix rising from the ashes of economic perversion.

\section{Acknowledgements}

\footnotetext{
${ }^{11}$ For a more detailed analysis of the similarities between Cole's own alternative and contemporary social movements see Dawson (2013) and Masquelier (2014).
} 
We would like to thank the two anonymous reviewers for their constructive comments on previous versions of this article.

\section{References}

Alperovitz, G. (2011) America Beyond Capitalism: Reclaiming our wealth, our liberty and our democracy, $2^{\text {nd }}$ edition, Boston, MA: Democracy Collaborative Press

Alperovitz, G. (2013) ‘The emerging paradoxical possibility of a democratic economy,’ in Shantz, J. and Macdonald, J. B. (eds) Beyond Capitalism: Building democratic alternatives for today and the future, New York: Bloomsbury

Bauman, Z. (1997) Postmodernity and its Discontents, Cambridge: Polity

Bauman, Z. (2000) Liquid Modernity, Cambridge: Polity Press

Benkler, Y. (2013) 'Practical anarchism: Peer mutualism, market power, and the fallible state,' Politics and Society, June, Vol 41(2): 212-251

Boltanski, L. (2002) 'The Left after May 1968 and the Longing for Total Revolution', Thesis Eleven, 69: 1-20.

Bourdieu, P. and Wacquant, L. (2001) 'NewLiberalSpeak: Notes on the Planetray Vulgate,' Radical Philosophy, Vol. 105

Braverman, H. (1974) Labor and Monoploy Capital: The Degradation of Work in the Twentieth Century, New York: Monthly Review Press

Burawoy, M. (2005) 'For public sociology,'American Sociological Review, February, Vol. 70: $4-2 / 8$

Cole, G.D.H. (1917) Self-government in Industry, London: George Bell \& Sons 
Cole, G.D.H. and Mellor, W. (1918) The Meaning of Industrial Freedom, The Herald: London

Cole, G.D.H. (1920) Social Theory, London: Methuen \& Co.

Cole, G.D.H. (1926) 'Loyalties', Proceedings of the Aristotelian Society, 26 (1925-1926), 151-70.

Cole, G.D.H. (1934) Some Relations between Political and Economic Theory. London: Macmillan \& Co.

Cole, G.D.H. (1938) Socialism in Evolution, London: Pelican Books

Cole, G.D.H. (1944) A Century of Cooperation, London: George Allen and Unwin Ltd

Cole, G.D.H. (1948) The Meaning of Marxism, London: Victor Gollancz Ltd

Cole, G.D.H. (1950) Essays in Social Theory, London: Macmillan

Cole, G.D.H. (1952) Politico-Economic Theories Part II (1850-). Lecture, Cole Collection, Nuffield College, University of Oxford. Box 55, Document E3/13/1/1-172.

Cole, G.D.H. (1957a) “William Morris as a Socialist,” London: William Morris Society

Cole, G.D.H. (1957b) The Case for Industrial Partnership, London: MacMillan \& Co LTD

Cole, G.D.H. (1957c) ‘Sociology and Social Policy’, British Journal of Sociology 8(2): 15871.

Cole, G.D.H. (1960) A History of Socialist Thought: Volume V, Socialism and Fascism 19311939. London: Macmillan

Cole, G.D.H. (1980) Guild Socialism Restated, London: Transaction Books 
Cole, G.D.H. (1993) 'Introduction,’ in Jean-Jacques Rousseau, The Social Contract and Discourses, London: Everyman

Chomsky, N. (1999) Profit Over People: Neoliberalism and Global World Order, London: Seven Stories Press

Chomsky, N. (2012) Occupy, London: Penguin.

Crouch, C. (2011) The Strange Non-Death of Neo-Liberalism, Cambridge: Polity Press

Dawson, M. (2013) Late Modernity, Individualization and Socialism: An Associational Critique of Neoliberalism, Basingstoke: Palgrave

Dawson, M. and Masquelier, C. (2015) ‘G.D.H. Cole: Sociology, Politics, Empowerment and 'How to be Socially Good', in Alex Law and Eric Royal Lybeck (eds) Sociological Amnesia: Cross-Current in Disciplinary History, Farnham: Ashgate, pp. 125-40

Doogan, K. (2009) New Capitalism ? The Transformation of Work, Cambridge: Polity Press

Flank, L. (2011) Voices from the 99 Percent: An Oral History of the Occupy Wall Street Movement, St Petersbug, Florida: Red and Black Publishers

Fuchs, C. (2011) 'Cognitive capitalism or informational capitalism? The role of class in the information economy,' in Michael Peters and Ergin Bulut (eds) Cognitive capitalism, Education and Digital Labor, New York: Peter Lang

Harvey, D. (1989) The Condition of Postmodernity: An Inquiry into the Origins of Cultural Change, Cambridge, MA: Blackwell

Harvey, D. (2005) A Brief History of Neoliberalism. Oxford: Oxford University Press.

Hirst, P. (1994) Associative Democracy: New Forms of Economic and Social Governance. Cambridge: Polity Press. 
Holthaus, L. (2014) G.D.H. 'Cole's International Thought: the Dilemmas of Justifying Socialism in the Twentieth Century,' The International History Review, April, online first

Jessop, B. (2002) The Future of the Capitalist State, Cambridge: Polity Press

Kasmir, S. (1996) The Myth Of Mondragon: Cooperatives, Politics, and Working-Class Life in a Basque Country, Albany: SUNY Press

Kumar, K. (1995) From Post-Industrial to Post-Modern Society, Oxford: Blackwell

Lamb, P. (2005) 'G.D.H. Cole on the General Will: A Socialist Reflects on Rousseau', European Journal of Political Theory, 4:3, 283-300.

Marx, K. (2000) Economic and Philosophical Manuscripts, in McLellan, D. Karl Marx: Selected Writings, Oxford: Oxford University Press

Masquelier, C. (2014) Critical Theory and Libertarian Socialism: Realizing the Political Potential of Critical Social Theory, New York: Bloomsbury

Piketty, T. (2014) Capital in the Twenty First Century, Boston, MA: Harvard University Press

Piore, M.J. and Sabel, C.F. (1984) The Second Industrial Divide: Possibilities for Prosperity, New York: Basic Books

Rousseau, J.J. (1993) The Social Contract and Discourses, London: Everyman

Shantz, J. and Macdonald, J. B. (eds) (2013) Beyond Capitalism: Building democratic alternatives for today and the future, New York: Bloomsbury

Simpson, M. (2006) Rousseau's Theory of Freedom, New York: Continuum

Stears, M. (2006) Progressives, Pluralists and the Problems of the State: Ideologies of the state in the United States and Britain 1909-1926, Oxford: Oxford University Press 
Warren, M.E. (2001) Association and Democracy, Princeton: Princeton University Press

Wolff, R. (2012) Democracy at Work: A cure for capitalism, Chicago: Haymarket Books

Wright, A. (1979) G.D.H. Cole and Socialist Democracy. Oxford: Oxford University Press.

Wyatt, C. (2011) The Defetishised Society: New Economic Democracy as libertarian alternative to capitalism, New York: Bloomsbury 